\title{
Multiculturalism: Discursive Practices
}

\author{
Vagif Deyrushevich Bayramov ${ }^{1}$, Yury Grigorievich Volkov ${ }^{2}$, Svetlana Aslanovna Lyausheva ${ }^{3}$, Oxana Yuryevna \\ Posukhova ${ }^{4} \&$ Sergey Ivanovich Samygin ${ }^{5}$ \\ ${ }^{1}$ Moscow State Humanitarian Economy University, Moscow, Russian Federation \\ ${ }^{2}$ Institute of Sociology and Regional Studies, the Southern Federal University, Rostov-on-Don, Russian \\ Federation \\ ${ }^{3}$ Department of Philosophy and Sociology, Adygea State University, Maikop, Russian Federation \\ ${ }^{4}$ Institute of Sociology and Regional Studies, the Southern Federal University, Rostov-on-Don, Russian \\ Federation \\ ${ }^{5}$ Rostov State University of Economics (RSUE), Rostov-on-Don, Russian Federation \\ Correspondence: Yury Grigorievich Volkov, Institute of Sociology and Regional Studies, the Southern Federal \\ University, Rostov-on-Don, Russian Federation. Tel: 7-863-264-1755. E-mail: infoippk@sfedu.ru
}

\author{
Received: March 30, 2015 Accepted: April 20, 2015 Online Published: May 14, 2015 \\ doi:10.5539/res.v7n7p195 URL: http://dx.doi.org/10.5539/res.v7n7p195
}

\begin{abstract}
The article investigates the problem of multiculturalism. The authors examine the discursive practices of multiculturalism in relation to the multinational, multicultural, and multiconfessional Russian society undergoing a long period of social transformation. The article analyzes the trends and processes in the space of intercultural and interethnic interaction in the world and in Russia. Historically formed modes of interaction, mutual recognition, and understanding of culturally national and culturally religious communities characterize the Russian multinational society. Particular attention is paid to the Islamic factor. The authors substantiate the necessity of taking into account the Islamic factor in the political life of the country based on achievement of inter-confessional and political consensus between the government and Muslim leaders, recognition of the autonomy of the Islamic rules not only in the spiritual realm, but also in the education of youth, family relations, public security and possibility of formulating own religious interests and claims. The article emphasizes the importance of preventing the imposition of a model of governing the state and society based on discrimination against citizens upholding secular and civic values. It is necessary to preserve the principle of separation of state and religion, which is very crucial for the preservation of Russia as a multiethnic democratic secular state.
\end{abstract}

Keywords: multiculturalism, interconfessional relations, interethnic relations, Islam, tolerance

\section{Introduction}

\subsection{Introduce the Problem}

The concept of multiculturalism society, which has seemingly subverted the schemes of assimilation and integration typical of social modernity, nowadays becomes a matter of crushing criticism by not only nationalists, but also left-wing leaders.

Why in the modern European society, in which the traditions of tolerance and minority rights are cultivated, do we observe the surge of negative emotions and assessments to the idea of multiculturalism based on the priority of equality of different cultural values, lifestyles and behavioral norms? The obvious answer is the problem of the so-called "Islamic" challenge, inefficiency of mutual recognition and trust between the cultural communities in the context of the deepening claims of the quantitatively increasing Islamic community to be not an equal, but the leading party in the social and political life of European countries.

\subsection{Importance of the Problem}

An attractive idea of civil rights priority over the collectivity of the ethnic group does not eliminate the risk of political non-viability of the state that does not have a consolidating supranational ideology and common national interests. Political correctness offered as a solution taboos real problems of disintegration under the cultural distinctions acquiring political properties. 
We can definitely say that practices of multiculturalism create new social phobia of identity loss and social collapse under the pressure of the "affirmative" law requirements violating the equality of rights-the only absolute democratic principle. Equalization of political rights should occur regardless of cultural identity, but the promotion of cultural diversity leads to the transfer, conversion of cultural peculiarity to political autonomy, exclusion, and implementation of ethnic privileges in the area of political field.

Universal civil rights, which are aimed at ensuring the security, stability and well-being of individuals, devalue in the context of alternative models of ethnic or confessional solidarities, in arising on the way of interaction between the individual and the society, the individual and the state of mediums in the form of institutions of interest intermediation legitimizing their existence with reference to preservation of cultural identity and claims to sovereignty in status of the minorities' elite.

\subsection{Relevant Scholarship}

The concept of multiculturalism was introduced into scientific discourse in the 1970s.

Sociologist Nathan Glazer noted that the term "multiculturalism" is often used in both positive and negative sense encompassing so diverse facts and phenomena that it is not easy to describe what is meant by multiculturalism (Glazer, 1977).

S. Huntington defined "multiculturalism" as "the essence of anti-European civilization" which "is a movement opposed to the monocultural hegemony of Eurocentric values, which has generally resulted in the marginalization of other ethnic cultural values ..." (Huntington, 2004).

Historian Arthur Schlesinger approached multiculturalism as ideology replacing social ideals of assimilation with fragmentation, and integration processes with separatism (Schlesinger, 1992).

Major contribution to the study of the multiculturalism phenomenon was made by so-called Australian school; in particular, I. Zubrzycki who emphasized that multiculturalism is primarily a political project of the state aimed at exposing the natural potential of such immigrant societies as the Australian, Canadian and American (Zubrzycki, 2003). Zubrzycki also wrote that multiculturalism could be also represented as a universal phenomenon associated with the identity of human values.

Ch. Kukathas identified five options of response to the problem of the cultural paradigms collision in his research: isolationism, assimilation, soft multiculturalism, hard multiculturalism, and apartheid. Soft multiculturalism seems the most acceptable option intending support of the general cultural field evangelizing equal treatment of ethnic cultures seeking to preserve their identity (Kukathas, 2004).

Thus, we see that the problem of multiculturalism, which was introduced into the scientific discourse in the 1970s, has been widely developed. However, the relevance of its study is still extremely high, as there is no unified approach to understanding the nature and role of multiculturalism in today's world. Moreover, in connection with the globalization gathering pace and intensifying migratory flows, intercultural interaction issues are among the most acute problems.

\section{Research Methodology}

J. Klausen in his volumetric study "The Islamic challenge" emphasizes that party ideologies do not always attract Muslims, having in mind that Islam as a faith determines the rejection of European ideological samples built on a secular basis (Klausen, 2005). Despite the desire of adherents to transfer religious differences to the level of individual self-expression or differences fitting into the framework of cultural pluralism, for the leaders of Muslim communities faith defines the attitude to political life and forms the position of rejection of secular politics while maintaining democratic institutions as a mean of expression, delegation and representation of the fundamentalist ideas in life of not only Islamic communities, as well as the impact of the hosting European communities on the political and legal culture in order to grant Islamic priorities the preferences, prohibition of criticism and debate.

Klausen also notes that politically active Muslims demonstrating centrist position close to the "left" political tradition are guided by "the logic of merger": "leftists" adhere to a positive migration policy, tend to have far-reaching compromises concerning the autonomy of migrant communities, and consistently oppose xenophobic attitudes. Obviously, for the representatives of the Islamic tradition, in which the faith is a way of organizing political activity, "left" appear for the useful allies, but in no way are the bearers of integration trends.

If the European centrists and "left" see multiculturalism as a scheme of ingression of foreign cultural groups to the European environment on conditions of respect for traditions and individual rights, in the context of preserving the religious identity, a process of forming parallel forms of political activity in the attitudes of 
Islamic communities leaders occurs. Within the community, the idea of tolerance is considered obviously alien and divisive, as evidenced by rather rigid attitude towards immigrants from Islamic environment occupying a secular politics niche.

The model of citizenship evangelized in modern liberal democratic state, according to the Russian researcher V. Malakhov, expands the boundaries of cultural pluralism, "encouraging" not only belonging to the multiplicity of cultural identities, but also a floating political status (Malakhov, 2006). Contagion of multiculturalism practices in the field of policy has serious consequences, as this refers to the revision of the national state model, in which citizenship is associated with a particular political community.

The concept of multiculturalism has emerged not due to the practice of migrant communities' growth and the need to address the problems of integration. Primarily, practices of multiculturalism were maintained and achieved leading positions in the political life of the contemporary European society as a parting with "colonial" and racist discourses. Public moods were fobbed off the complex of overcoming superiority and affirmation, an integration scheme, that is the acquisition of cultural and political loyalty by migrants became to be considered as forcing, abusing, and violating the rights of migrants. But provision on the integration as reproduction of cultural and social inequality can be regarded as the most serious argument: the migrant forced to go through the stage of socialization is seen as a potential citizen requiring verification of social, cultural, and linguistic competence. The logic of separation is detected in the differentiation of seemingly strong cultural identity. The migrant cannot enter the cultural space without parting with his "past". Multiculturalism allowing the possibility of staying a nativity carrier liberalizes conditions of political loyalty, which, as the tendency of the "rise of intolerance" shows, leads to the ethnicization of political space, or, as it sounds in the context of the Islamic challenge, to involving the society in confessional discourse containing the risk of narrowing the norms of modernity, democratic procedures and appraisals.

Liberal thought falls into the "trap" of orientalism, when the multiculturalism encourages traditionalism, identifies the migrant with the cultural or confessional community. According to E. Said, the "Orient", as a semantic mythological construct, having origins from the time of Napoleon's invasion of Egypt, looks non-vanishing, as European knowledge and appraisals of the East are perceived as the nature, the essence in the broad sense of non-European outlook (Said, 2003). Multiculturalism is the principle of autonomous co-existence of cultures based on the negative mutual recognition, the division of sociocultural personality types, which are formed in different cultural and civilizational conditions.

Externally releasing the European consciousness from the burden of colonial discourse, multiculturalism standards jeopardize erosion of integral values of society, as tolerance cannot be a solidarity idea, regulating only issues of neutralization of cultural conflicts and tensions. According to J. Klausen, Islamic discursive practices contribute to the construction of groups, which do not virtually exist (Klausen, 2005). Identification of "non-practicing" Muslims with the community described as Islamic create the effect of the rise of influence of divisive trends in society, in a dispute between the Islamism leaders and leaders of the secular policy.

It is noteworthy that immigrants from Latin America and Africa quite seamlessly integrate into the European society, as there are no neoethnic or quaziconfessional schemes used against them. Multiculturalism can be hold accountable for promoting distrust and segregation of public life. We can agree that the practice of imposed integration and individual's refusal of nativeness has been discredited during the past period, but we cannot ignore the fact of the growing trend of mutual exclusion of migrants and "native" population in the society, when accusations of violating the basic social and ethical norms become a potent political argument.

The provision on the fact that nation is a form of civil and political self-determination refers to the concept of the nation state, which seems redundant and unnecessary in the context of the theory of multiculturalism. It seems an obstacle to establishment of the association of national and cultural communities narrowing influence of the state to the limits of provisioning the social services and settlement in the legal field of culturally ethnic and culturally religious conflicts.

E. Said explains the reappearance of orientalism in the modern Western theory by the fact that although orientalism is rejected firmly and irrevocably, its existence is confirmed by the discursive practice of exotericism, mysticism, and irrationalism incidental to the East (Said, 2003). On this basis, orientalism cannot be considered in a neutral sense, since it contains significant political implications. If the representatives of the eastern civilization tend to perceive the European political and legal norms skeptically and to see manifestations of secular and rational thought in the attempt to avoid accusations of racism and prejudice, multiculturalism is considered as an alternative to orientalism.

This attitude is consistently pursued by the supporters of "leftism", for whom the theory of ethnic relations is the 
naturalization of a racist behavior directed at maintaining the threshold of tolerance and cultural distance (Balibar \& Wallerstein, 2003). Accusatory bias is explained by the fact that collectivity is attributed with the cultural identity, which leads to the segregation and discrimination of individuals on cultural grounds.

Obviously, being aware of the limitation of multiculturalism, the "left" theoreticians write that no theoretical discourse on the dignity of all cultures can serve as the compensation for the assimilation as an immutable fact of integration into the European society (Balibar \& Wallerstein, 2003).

Within the undertaken criticism, multiculturalism is evaluated as a tool for cultural domination in the context of permissiveness of other cultural identities on condition of marginalization and determination of social reproduction antiquity requiring long and careful treatment. In these circumstances, multiculturalism is associated with uncertainty, since it is unclear who the bearer of cultural diversity is-individuals or communities (Walzer, 2000). Referring to the need for protection and implementation of democratic values, the theorists of multiculturalism face the practice of transposition of national and cultural values into the political language, or the language of morals. And this can bring into question the obligingness of adoption of democratic procedures in view of contradiction to certain religious or moral norms.

It may seem that the very concept of multiculturalism is a product of "despair", inability to resolve the complexities of cultural diversity passing into the political sphere in the context of Western democratic values. In the position of tolerance to "otherness" can be seen a kind of offer of compensation for the failure of political integration containing more defeats than successes. If we follow the classical policy formulas, the prospect of change in the political elite under the cultural identification reasons becomes real and the theory of multiculturalism reduces the potential risks of cultural inclusion establishing the boundaries of autonomy and alternatives permitted in the non-political sphere (Volkov, 2013).

Reflecting on the American multiculturalism, M. Walzer suggests that advocated differences based on self-defense, tolerance, and civil rights take an Americanized form (Walzer, 2000). According to Walzer, the scheme of cultural differences, supported within the framework of democratic consensus culture, creates differentiation with the bearers of similar values from other societies. This occurs because it instills cultural and ethnic minorities a sense of Americanism, the faith in a free society and human rights, makes them followers of the American Freedom Charter, unintentionally forms the attitude to the kin from the perspective of "democratic superiority".

Conclusions of M. Walzer seem too optimistic: there is a real problem of assertion of political autonomy by the Spanish-American and African-American minorities in the American society. But the trend of isolation has not reached a critical level gaining strength as a legitimation of language, culture, history, and implementation of the project of multicultural education. The situation is complicated by the fact that the majority of migrants is perceived by the American society as consumptive, containing the possibilities of solving social issues, but limited in the cultural and value dimension. Another important consequence, according to M. Walzer, is that the most "noisy" and extremist in the field of cultural identity groups are the most disadvantaged and vulnerable (Walzer, 2000). It can be assumed that the practice of multiculturalism encourages social segregation reproducing ethnic and racial myths, justifies social inequality by the reference to the uniqueness of cultural traditions, ways of living and impossibility of universal social standards.

A common place of multiculturalism is the reproduction of cultural and symbolic differences prevailing in the dispute about who should be considered "kin" and "strange." Recognizing the right to cultural autonomy, we cannot but become aware of the prospects of minorities isolation, which, in spite of positive discrimination, reproduce models of lagging and dependence in the communication between those who are considered citizens. The trend of conflictogenity related to impingement on the idea of equality in order to compensate social maladjustment invades the political sphere.

Institutional environment of multiculturalism supports cultural affections through administrative and legal practices of mutual neutrality. It fixes the understanding of "oneself" out of the context of addressing to "others" as the subjects. In this case, tolerance can be identified as a fundamental principle of multiculturalism, with the approval of stratification, specialization, and hereditary separation. There is a risk of retention of an individual within the community, regardless of individual aspirations, as well as of establishing ties between citizens based on indifference to the rights of the individual. Thus, this individual can be called by the name of the community, but his freedom will be sacrificed.

S. Benhabib, a professor from the United States, having studied the issues of cultural identity for a long time, said that since the mass culture does not educate and change anybody, the autonomous logic of cultures, linking the meaning of life with the identity of the individual, is welcomed (Benhabib, 2003). Absolutization of culture 
as a property of a nation or race, or identification of culture with religious and confessional or moral norms, which contains even greater risk, leads to the fact that cultural identities are beyond the reach of the critical analysis.

The basis for apologetization is the naturalization of cultural groups and the prescribed statutory procedure, under which the independence of cultures requires finding procedural rules of interaction and unspoken prohibition of the comparison on the criterion of absolute dissimilarity of uniqueness. Multiculturalism includes the desired objective of cultural unity creation through discursive interventions: this is a guilt of orientalism, which can reconstruct the marginal events into the imaginary integrity to perceive other cultures as a sign of regulatory differences.

The inconsistency of views is smoothed by conventional adjustment for a political correctness, attaching uniformity to the procedures of familiarization with the cultures through allocation of only "positive" elements and influences leading to an apparent "overrun", when for the sake of political correctness the antiquity acquires socially relevant meaning. Internal differences between the territorial and social and class groups disappear, for what most commonly religious and mythological narratives are used. And this, in turn, promotes the formation of confessional communities using religious language for the position of an active attack, preserving the sphere of political and legal autonomy with the guarantee of social benefits. In this situation, religious or moral authorities have a greater impact on the members of the community than government institutions, as the prevailing position is the position of unity on a religious or moral basis in order to become a leading political force in the future. Community leaders perceive Western democracy as weak because of its disunity, corruption against the onslaught of the unified political will based on the fundamental spiritual principles.

Orientalism as a designing of traditional symbols and values similar to the European thinking structure defines the extension of the political realm, adding subjectivity to marginal elements in another cultural community, which would not have any prospects to be recognized and to be presented in the situation of universal cultural practices.

The desire to implement the principle of tolerance into the public life is contrary to the tradition of "privatization" of tolerance as a position of indifference and non-interference in the private aspects of life. Generalization of this procedure is the possibility, on the basis of otherness, to position a significant challenge to society: tolerance, political correctness, multiculturalism are ways to avoid conflicts with the riskogenics of violence towards others in the context of hope for overcoming social and cultural gaps based on non-violence.

A multicultural society is not a sphere of absolute freedom, it involves the repressiveness to those who violate the rules of tolerance and adhere to the postulate of national cultural homogeneity. Can such a formula of social coexistence be interpreted as refutation of orientalism, tabooing of colonial and racist discourses? The legal practice in the form of affirmative law, in our opinion, not altering its understanding of the complexity of cultural and symbolic examples, multiplies proneness to conflicts through reproduction of the "underdevelopment" stereotype attributed to migrants, as people unable to adapt to new social and cultural environment, without the help of state and public structures and without exercising their civil rights so as not to cause complaints of representatives of the host community in the social infantilism and clientelism.

\section{Results and Discussion}

Historically, the category of multiculturalism is not traditional for the Western community and leads to a break with the modernity idea of person as an autonomous intelligent individual with inalienable rights. Tolerance in this context can be understood as the principle of promoting self-reliance that does not accept what is not allowed by state law. As a postmodernist scheme, multiculturalism alters the principle of tolerance, claiming that certain groups of people may be the subject of tolerance, despite the disagreement with existing cultural and legal practices. Herewith, the risk of erosion of the rightful state and the political nation ideology associated with it increases. The western community trying to avoid the use of force through the models of assimilation and integration gets into a situation of discrediting and devaluating the basic values, as the bearers of "otherness" have undoubtedly more preferences and freedoms while being restricted in the performance of their duties and occupying beneficial positions in the possession of rights. In this context, the social virtues become a burden, a lumber, a limiter in the efforts of a person acting solely in the legitimate and legal social fields. The principle of competition undergoes deformation, where benefits are obtained by voluntary or involuntary violators of social and cultural norms, and loyal citizens experience social deprivation under the conditions of mandatory support and tolerance in relation to "the others".

Introduction of the idea of multiculturalism in Russia is associated with the liberal ideologem, the desire to build a society of tolerance and civility on the Western pattern. A system analysis of the examined trends determines 
the critical assessment of the multiculturalism supporters' activity not so much with the fact that the Western society has become disappointed in the ideological construct of "reconciliation" and the co-existence of cultural differences, as with non-survival of tolerance in the legal sense as a way of humanization of social life with the ideas of freedom and justice incorporated in it in the Russian social and cultural space (Ilyinskaya, 2007).

\section{Conclusions}

The Russian multinational society is characterized by the historically formed modes of interaction, mutual recognition, and understanding of culturally national and culturally religious communities. Russian Islam is traditionally loyal to the government and focused on social and moral virtues, as well as spiritual education of believers. In this situation, the Russian government has always sought democratism with regard to Islam despite some "overexposures" in etatization of orthodoxy (Mizun \& Mizun, 2004).

Attempts to present terrorism, national separatism, and ethno-national tensions as the results of desecularization of the society during the post-Soviet period, acquisition of opportunities to influence and express interests in the social and political life by religious confessions are tendentious.

A. Malashenko emphasizes that the Russian society is characterized, on the one hand, by the growing xenophobia, a part of which is hostility to Islam, and on the other hand, by the opposition of the active part of the Muslims to public policy (Malashenko, 2007).

Russia needs the concept of multiculturalism, based on the achievement of interconfessional and political consensus between the government and Muslim leaders, recognition of the autonomy of the rules of Islam not only in the spiritual realm, but also in the education of youth, family relations, public security and possibility of formulating own religious interests and claims.

\section{References}

Balibar, E., \& Wallerstein, I. (2003). Race, nation, class. Moscow: Ecce Homo.

Benhabib, S. (2003). The claims of Culture. Moscow: Logos.

Glazer, N. (1977). We are all multiculturalists now. Cambridge: Harvard university press.

Huntington, S. (2004). Who are we? The challenges to America's national identity. Moscow: Tranzikniga.

Ilyinskaya, S. G. (2007). Tolerance. Moscow: Praxis.

Klausen, J. (2005). The Islamic challenge. Oxford.

Kukathas, C. (2004). Theoretical foundations of multiculturalism. DIALOG.ua: Independent information and analytical resource. Retrieved from http://econfaculty.gmu.edu/pboettke/workshop/fall04/theoretical_foundations.pdf

Malakhov, V. S. (2006). The nation-state in the face of cultural pluralism. Logos, 2.

Malashenko, A. V. (2007). Islam for Russia. Moscow: ROSSPEN Publishers.

Mizun, Yu. V., \& Mizun, Y. G. (2004). Islam and Russia. Moscow: "Veche".

Said, E. (2003). Orientalism. London: Penguin.

Schlesinger, A. M. (1992). The disuniting of America. Reflections on a multicultural society (2nd ed.). N. Y.-L.: Whittle Books.

Volkov, Yu. (2013). Creative Tendencies in Regional Elites' Activity. World Applied Sciences Journal, 28(2), 180-184. Retrieved from http://www.idosi.org/wasj/wasj28(2)13/6.pdf

Walzer, M. (2000). On toleration. Moscow: Idea-Press, House of intellectual books.

$\begin{array}{llllll}\text { Zubrzycki, } & \text { J. } & \text { (2003). } & \text { Big } & \text { Ideas. } & \text { Retrieved }\end{array}$ http://www.abc.net.au/radionational/programs/bigideas/wisdom-interviews-jerzy-zubrzycki/3533890\#transc ript

\section{Copyrights}

Copyright for this article is retained by the author(s), with first publication rights granted to the journal.

This is an open-access article distributed under the terms and conditions of the Creative Commons Attribution license (http://creativecommons.org/licenses/by/3.0/). 